\title{
Romanian Language
}

National Cancer Institute

\section{Source}

National Cancer Institute. Romanian Language. NCI Thesaurus. Code C154090.

An Eastern Romance language spoken as a native language, primarily in Romania and Moldova. 